\title{
Differential effects of tetrahydropyridinol derivatives on $\beta$-catenin signaling and invasion in human hepatocellular and breast carcinoma cells
}

\author{
ANANDAM KASIN YADUNANDAM ${ }^{1}$, JIN-SOO YOON $^{2}$, YEON TAE JEONG $^{3}$, \\ WOE-YEON KIM ${ }^{4}$, SANG-YEOL LEE ${ }^{4}$ and GUN-DO KIM ${ }^{1}$
}

\begin{abstract}
${ }^{1}$ Department of Microbiology, College of Natural Sciences, Pukyong National University, Busan 608-737, Republic of Korea;
${ }^{2}$ Department of Immunology, John Curtin School of Medical Research, Australian National University, Canberra, Australia;

${ }^{3}$ Department of Image Science and Engineering, College of Engineering, Pukyong National University, Busan 608-737;

${ }^{4}$ Division of Applied Life Science, Plant Molecular Biology and Biotechnology Research Center,

Gyeongsang National University, Jinju 660-701, Republic of Korea
\end{abstract}

Received October 9, 2014; Accepted May 15, 2015

DOI: $10.3892 / \mathrm{ijmm} .2015 .2240$

\begin{abstract}
In continuation of previous efforts to investigate the biological potency of tetrahydropyridinol derivatives, the present study synthesized three target compounds: $\mathrm{N}$-(bromoacetyl)-3carboxyethyl-2,6-diphenyl-4-O-(pentafluorobenzoyl)- $\Delta 3$-tetrahydropyridine (5a), N-(chloroacetyl)-3-carboxyethyl-2,6diphenyl-4-O-(pentafluorobenzoyl)- $\Delta 3$-tetrahydropyridine (5b) and N-(2-bromopropanoyl)-3-carboxyethyl-2,6-diphenyl-4-O(pentafluorobenzoyl)- $\Delta 3$-tetrahydropyridine (5c), and examined their anticancer potency. Experiments were performed using the Sk-Hep1 and Hep3B human hepatocellular carcinoma cell lines and MDA-MB-231 breast adenocarcinoma cell line. Among the three compounds, $5 \mathrm{a}$ and $5 \mathrm{~b}$ were comparably and significantly cytotoxic to the Sk-Hep1,Hep3B and MDA-MB-231 cells. The highest level of cytotoxicity was detected in theSk-Hep1 cells with half maximal inhibitory concentrations for compounds $5 \mathrm{a}$ and $5 \mathrm{~b}$ at 12 and $6 \mu \mathrm{M}$, respectively. These two compounds induced cell cycle arrest in the Sk-Hep1 and MDA-MB-231 cells through the downregulation of $\beta$-catenin and upregulation of glycogen synthase kinase- $3 \beta$ and E-cadherin. By contrast, 5a and 5b induced G1 arrest in the
\end{abstract}

Correspondence to: Professor Gun-Do Kim, Department of Microbiology, College of Natural Sciences, Pukyong National University, 45 Yongso-ro, Nam-gu, Busan 608-737, Republic of Korea E-mail: gundokim@pknu.ac.kr

Abbreviations: HCC, hepatocellular carcinoma; EMEM, Eagle's minimal essential medium; BEBM, bronchial epithelial cell basal medium; FBS, fetal bovine serum; WST-1 ${ }^{\circledR}$, 2-(4-iodophenyl)3-(4-nitrophenyl)-5-(2,4-disulfophenyl)-2H-tetrazolium, monosodium salt; PBS, phosphate-buffered saline

Key words: $\beta$-catenin, breast carcinoma, cell cycle, cell signaling, hepatocellular carcinoma, tetrahydropyridinol derivatives
Hep3B cells by modulating the $\mathrm{p} 21$ and $\mathrm{p} 27$ cell cycle regulatory molecules and cyclin-dependent kinase 2 . In addition, 5a and $5 \mathrm{~b}$ significantly inhibited the invasion of Sk-Hep1 and MDA-MB-231 cells. These results suggested that the 5a and $5 \mathrm{~b}$ compounds induce cell cycle arrest by suppressing Wnt/ $\beta$-catenin signaling in highly invasive Sk-Hep1 and MDA-MB-231 cells, and by inducing p53 independent cell cycle arrest in Hep3B cells.

\section{Introduction}

Hepatocellular carcinoma (HCC) is one of the most aggressive types of cancer in humans and remains the second leading cause of cancer-associated mortality worldwide. The prognosis of HCC patients is poor, with a 5-year survival rate of $<12 \%$, predominantly due to late diagnosis, early metastasis and high resistance to chemotherapy (1). Despite advances in diagnostic techniques, drug development and surgical procedures, the incidence of $\mathrm{HCC}$ is almost equal to the mortality rate $(1,2)$. Local surgical ablation therapies can also prolong survival rates, however, due to locally extended and metastasized disease, only $15 \%$ of patients are eligible for resection, which is often followed by local recurrence (3). In HCC, the rates of incidence and mortality are higher in males than in females (3). HCC is generally poorly responsive to cytotoxic chemotherapy. Sorafenib, a Food and Drug Administration approved agent for HCC, only increases median survival rates from $\sim 8-10$ months (4). One of the major causes of morbidity and mortality associated with the disease is poor understanding of the molecular signaling pathway, and novel therapeutic strategies and drugs are desirable for HCC.

The Wnt/ $\beta$-catenin signaling pathway is important in embryonic development and adult homeostasis, including proliferation, migration and differentiation $(5,6)$. The role of $\beta$-catenin was first recognized as a membrane-associated protein, involved in cell-cell adhesion. Cytoplasmic $\beta$-catenin binds to the carboxyl terminus of E-cadherin at the plasma 
membrane, and this complex recruits $\alpha$-catenin, which further recruits other structural proteins to form the cell-cell junctions $(7,8)$. In addition to its role as an adhesion protein, $\beta$-catenin can also act as a transcription co-activator. $\beta$-catenin is a key component of downstream signaling in the Wnt/Wingless pathway, which is important to embryonic development. This pathway is also involved in disease development if misregulation of $\beta$-catenin occurs (9). In development, Wnt protein binds to the Frizzled receptor and inhibits the adenomatous polyposis coli (APC)/glycogen synthase kinase-3 $\beta$ (GSK-3 $\beta$ ) complex, which phosphorylates $\beta$-catenin, targeting it to proteasomal degradation. When $\beta$-catenin is protected from degradation, it enters the nucleus and associates with the T-cell factor and lymphoid enhancer factor-1 (TCF/LEF-1) family of transcription factors, and this association activates the transcription of $\beta$-catenin target genes, including regulators of cell growth and proliferation, modulators of cell death pathways and cell-cell communication (10). Several studies have demonstrated that the $\mathrm{Wnt} / \beta$-catenin pathway is activated in $\mathrm{HCC}$, and this appears to be important in the aggressive nature of this disease, including its resistance to chemotherapy (11-13). Analyses of different genetic alterations have led to the identification of several major oncogenic pathways, which are deregulated in $\mathrm{HCC}$, including the $\mathrm{p} 53, \mathrm{Rb}, \mathrm{E}$-cadherin and Wnt/ $\beta$-catenin pathways (14).

In continuation of previous studies on tetrahydropyridinol derivatives as antibacterial and antimycobacterial agents $(15,16)$, the present study synthesized three novel analogs, N-(bromoacetyl)-3-carboxyethyl-2,6-diphenyl-4-O-(pentafluorobenzoyl)$\Delta 3$-tetrahydropyridine (5a), N-(chloroacetyl)-3-carboxyethyl-2,6-diphenyl-4-O-(pentafluorobenzoyl)- $\Delta 3$-tetrahydropyridine (5b) and N-(2-bromopropanoyl)-3-carboxyethyl-2,6diphenyl-4-O-(pentafluorobenzoyl)- $\Delta 3$-tetrahydropyridine (5c), and investigated their anticancer effects on human HCC and breast cancer cell lines.

\section{Materials and methods}

Synthesis of tetrahydropyridinol derivatives. All solvents and reagents used in the present study were of reagent grade, obtained from commercial sources and used without further purification, unless otherwise stated. The course of the reactions and purity of the products were assessed by using TLCon Silica Gel 60 F254 (Sigma-Aldrich, St. Louis, MO, USA) pre-coated plates. The melting points were read and recorded using an Electrothermal-9100 (Shimadzu, Kyoto, Japan) instrument. The nuclear magnetic resonance (NMR) spectra were run on a JNM ECP-400 instrument (JEOL, Ltd., Tokyo, Japan), operating at $400 \mathrm{MHz}$ for $1 \mathrm{~h}$ at $100.6 \mathrm{MHz}$ for complete proton decoupled ${ }^{13} \mathrm{C}$, using $\mathrm{CDCl}_{3}$ (Sigma-Aldrich) as a solvent and tetramethylsilane (TMS; Sigma-Aldrich) as an internal standard. The chemical shift values were reported in parts/million (ppm) relative to TMS, or with the solvent reference relative to TMS, used as the internal standard $\left(\mathrm{CDCl}_{3}\right.$; $\delta=7.26 \mathrm{ppm}$ for proton and $77.00 \mathrm{ppm}$ for carbon NMR). Mass spectra were obtained using a JMS-700 (JEOL, Ltd.) instrument. Purification of the final compounds was performed using silica gel (Sigma-Aldrich) (200-400 mesh-60A). The commercially available methylpentafluorobenzoate 1 upon base hydrolysis furnished the corresponding acid 2 (Fig. 1).
Compounds $4 \mathrm{a}-4 \mathrm{c}$ were obtained using methods described in our previous studies $(15,16)$. The desired esters, $5 \mathrm{a}-5 \mathrm{c}$, were synthesized by treating $4 \mathrm{a}-4 \mathrm{c}$ with pentafluorobenzoyl chloride (Sigma-Aldrich), which was obtained from acid 2 (Fig. 1) via thionyl chloride (Sigma-Aldrich) treatment in moderate yields $(61-81 \%)$

Synthesis of pentafluorobenzoyl chloride. Pentafluorobenzoic acid (2-4) was obtained by base hydrolysis of methylpentafluorobenzoate (Sigma-Aldrich) in methanol. To a mixture of pentafluorobenzoic acid $(0.005 \mathrm{~mol})$ in dry toluene $(15 \mathrm{ml}$; Sigma-Aldrich), freshly distilled thionyl chloride $(2 \mathrm{ml})$ was added and refluxed for $\sim 6 \mathrm{~h}$. The reaction mixture was cooled and the solvent was evaporated in vacuo. Another $10 \mathrm{ml}$ of toluene was added to the reaction mixture and complete evaporation of the contents was performed again. The residue remaining was dissolved in dry DCM (Sigma-Aldrich) and was used for esterification with the respective hydroxyl derivatives $(4 a-4 c)$ to obtain the desired target compounds $(5 a-5 c)$.

Synthesis of $5 a-5 c$. To an ice cooled solution of the respective $\mathrm{N}$-acyl derivatives $4 \mathrm{a}-4 \mathrm{c}(0.005 \mathrm{~mol})$ in dry DCM $(20 \mathrm{ml})$, either DMAP or $\mathrm{NEt}_{3}(0.015 \mathrm{~mol}$ each) (both from Sigma-Aldrich) was added and stirred well. To this, a solution of pentafluorobenzoylchloride in dry DCM was added drop-wise and stirred at room temperature over a period of $5 \mathrm{~h}$. Following completion of the reaction, the solvent was removed in vacuo, the residue was dissolved in ethyl acetate, and washed with bicarbonate, water and then brine. The organic layer was dried over $\mathrm{Na}_{2} \mathrm{SO}_{4}$, and the residue obtained by evaporation was purified in a column (0.5:10-1:10, ethyl acetate:hexane) to obtain the pure products.

Composition of $N$-(bromoacetyl)-3-carboxyethyl-2,6-dipheny l-4-O-(pentafluorobenzoyl)- $\Delta^{3}$-tetrahydropyridine $(5 a)$. Yield: $65 \%$, a semi solid. ${ }^{1} \mathrm{H}$ NMR $\left(400 \mathrm{MHz} ; \mathrm{CDCl}_{3}\right) \delta \mathrm{ppm}$ : 7.19-7.03 (m, 10H); 6.88 (bs, 1H), 5.51 (bs, 1H), 4.31 (d, $J=12.86 \mathrm{~Hz}, 1 \mathrm{H}), 4.16$ [d (not resolved well), 1H], $4.05(\mathrm{q}$, $J=7.05 \mathrm{~Hz}, 2 \mathrm{H}), 3.14$ (dd, $J=17.84 \mathrm{~Hz}, J=4.98 \mathrm{~Hz}, 1 \mathrm{H}), 2.98$ (dd, $J=17.84 \mathrm{~Hz}, J=6.22 \mathrm{~Hz}, 1 \mathrm{H}), 0.99$ (t, $J=7.05 \mathrm{~Hz}, 3 \mathrm{H}) .{ }^{13} \mathrm{C} \mathrm{NMR}$ $\left(100 \mathrm{MHz} ; \mathrm{CDCl}_{3}\right) \delta$ ppm: 166.57, 162.42, 157.23, 152.79, $148.09(\mathrm{~m}), 145.47(\mathrm{~m}), 139.04(\mathrm{~m}), 138.15,138.02,128.51-126.76$ (phenyl carbons), 120.17, $103.13\left(\mathrm{t}, J_{\mathrm{C}-\mathrm{F}}=11.14\right), 61.18,55.34$, 53.82, 42.33, 33.20, 13.64; MS [electrospray ionisation (ESI), positive] $\mathrm{m} / \mathrm{z}$ calculated for $\mathrm{C}_{29} \mathrm{H}_{21} \mathrm{BrF}_{5} \mathrm{NO}_{5}(\mathrm{M}+\mathrm{H})$ : 637.05; identified 637.3.

Composition of $N$-(chloroacetyl)-3-carboxyethyl-2,6-dipheny l-4-O-(pentafluorobenzoyl)- $\Delta^{3}$-tetrahydropyridine (5b). Yield: $81 \%$. White solid, mp $142-144^{\circ} \mathrm{C} .{ }^{1} \mathrm{H}$ NMR $(400 \mathrm{MHz}$; $\mathrm{CDCl}_{3}$ ) $\delta$ ppm: 7.20-7.02 (m, 10H, phenyl protons); 6.95 (bs, 1H), $5.51(\mathrm{bs}, 1 \mathrm{H}), 4.31(\mathrm{~d}, J=12.86 \mathrm{~Hz}, 1 \mathrm{H}), 4.14$ [d (not resolved well), $1 \mathrm{H}], 4.06(\mathrm{q}, J=7.05 \mathrm{~Hz}, 2 \mathrm{H}), 3.14(\mathrm{dd}$, $J=17.84 \mathrm{~Hz}, J=5.39 \mathrm{~Hz}, 1 \mathrm{H}), 2.98(\mathrm{dd}, J=17.43 \mathrm{~Hz}, J=6.22 \mathrm{~Hz}$, $1 \mathrm{H}), 0.99$ (t, $J=7.05 \mathrm{~Hz}, 3 \mathrm{H}) ;{ }^{13} \mathrm{C} \mathrm{NMR}\left(100 \mathrm{MHz}, \mathrm{CDCl}_{3}\right)$ $\delta$ ppm: 166.62, 162.44, 157.24, 152.78, $148.13(\mathrm{~m}), 145.40(\mathrm{~m})$, $139.06(\mathrm{~m}), 138.19,138.03,128.53-126.72$ (phenyl carbons), $120.20,103.17$ (t, $\left.J_{\mathrm{C}-\mathrm{F}}=11.19\right), 61.19,55.27,53.83,42.32,33.23$, 13.65; MS (ESI, positive) $\mathrm{m} / \mathrm{z}$ calculated for $\mathrm{C}_{29} \mathrm{H}_{21} \mathrm{ClF}_{5} \mathrm{NO}_{5}$ $(\mathrm{M}+\mathrm{H})$ : 593.1; identified 593.3. 


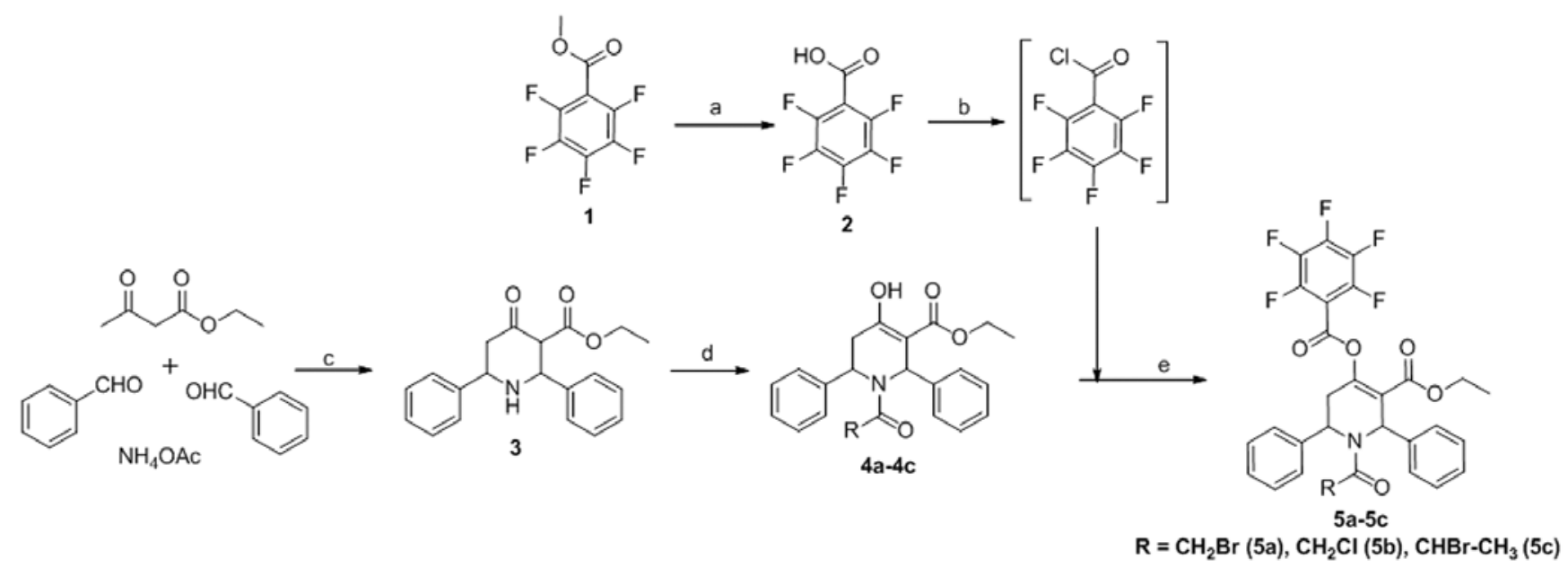

Figure 1. Synthesis of the tetrahydropyridinol derivatives 5a-5c. (a) Aq. $\mathrm{NaOH}, \mathrm{MeOH} /$ Water, rt; (b) thionyl chloride, dry toluene; (c) ethanol, $50^{\circ} \mathrm{C}$, overnight; (d) RCOCl, NEt3; (e) RCOCl, dry DCM, DMAP or NEt3.

Composition of $N$-(2-bromopropanoyl)-3-carboxyethyl-2,6-d iphenyl-4-O-(pentafluorobenzoyl)- $\Delta^{3}$-tetrahydropyridine $(5 c)$. Yield: $61 \%$, a white solid, mp 140-141 ${ }^{\circ} \mathrm{C} .{ }^{1} \mathrm{H}$ NMR $(400 \mathrm{MHz}$, $\left.\mathrm{CDCl}_{3}\right) \delta$ ppm: 7.19-7.03 (m, 10H), $6.98(\mathrm{~s}, 1 \mathrm{H}), 5.51(\mathrm{~s}, 1 \mathrm{H})$, 4.65 [q (not resolved well), 1H], 4.02 [q (not resolved well), 2H], 3.15 (s, 2H), 1.87 (d, J=6.22 Hz, 3H), 0.96 (t, $J=7.05 \mathrm{~Hz}$, $3 \mathrm{H}) ;{ }^{13} \mathrm{C}$ NMR $\left(100 \mathrm{MHz}, \mathrm{CDCl}_{3}\right) \delta \mathrm{ppm}: 169.13,162.40$, 157.29, 152.24, 148.06 (m), 145.60 (m), 139.08 (m), 138.54, 138.43, 128.64-126.26 (phenyl carbons), 119.97, $103.31(\mathrm{t}$, $\left.J_{\text {C-F }}=11.15\right), 61.07,55.07,53.11,39.10,32.50,22.01,13.62 ; \mathrm{MS}$ (ESI, positive) $\mathrm{m} / \mathrm{z}$ calculated for $\mathrm{C}_{30} \mathrm{H}_{23} \mathrm{BrF}_{5} \mathrm{NO}_{5}(\mathrm{M}+\mathrm{H})$ : 651.07; identified 651.1.

Biology. All the cell lines used in the present study were purchased from the American Type Culture Collection (ATCC; Manassas, VA, USA). All the cells were treated with the half maximal inhibitory concentration $\left(\mathrm{IC}_{50}\right)$ of each compound for the indicated durations. The $\mathrm{IC}_{50}$ concentrations were determined using Microsoft excel: $12 \mu \mathrm{M}$ of $5 \mathrm{a}$ and $6 \mu \mathrm{M}$ of $5 \mathrm{~b}$ for the Sk-Hep1 cells; $24 \mu \mathrm{M}$ of $5 \mathrm{a}$ and $11 \mu \mathrm{M}$ of $5 \mathrm{~b}$ for the Hep3B cells; $48 \mu \mathrm{M}$ of $5 \mathrm{a}$ and $20 \mu \mathrm{M}$ of $5 \mathrm{~b}$ for the MDA-MB-231 cells were used and the cells were treated with the compounds for $24 \mathrm{~h}$ at $37^{\circ} \mathrm{C}$. An antiproliferative assay was performed using a previously described method (17) with modifications.

Cell culture and antiproliferative assay. Human HCC Sk-Hep1 and Hep3B cells were maintained in minimum essential medium with Earle's balanced salts (MEM/ EBSS), containing $10 \%$ fetal bovine serum (FBS) at $37^{\circ} \mathrm{C}$ in a humidified atmosphere containing $5 \% \mathrm{CO}_{2}$ in air. The human breast adenocarcinoma MDA-MB-231 cells and non-cancerous human embryonic kidney HEK293 cells were maintained in Dulbecco's modified Eagle's medium (DMEM) containing $10 \% \mathrm{FBS}$ at $37^{\circ} \mathrm{C}$ in a humidified atmosphere containing $5 \% \mathrm{CO}_{2}$. The THLE-3 human normal liver cells were maintained in bronchial epithelial cell basal medium (BEBM) containing $10 \% \mathrm{FBS}$ at $37^{\circ} \mathrm{C}$ in a $\mathrm{CO}_{2}$ incubator. Stock solutions $(10 \mathrm{mM})$ of the three compounds were obtained by dissolving them in $100 \%$ dimethyl sulfoxide (DMSO) and the stock solution of the 3 different compounds was diluted with distilled water to yield a concentration of $1 \mathrm{mM}$ for treating the cells. Each well of a 96-well tissue culture microtiter plate was inoculated with $100 \mu \mathrm{l}$ complete medium containing $1 \times 10^{4}$ cells. The plates were incubated at $37^{\circ} \mathrm{C}$ in a humidified $5 \% \mathrm{CO}_{2}$ incubator for $24 \mathrm{~h}$ prior to the experiments. Following removal of the medium, $100 \mu \mathrm{l}$ fresh medium containing the compound at different concentrations was added to each well $(4,8,12,16$, $20 \mu \mathrm{M}$ of $5 \mathrm{a}$ for the HEK293, THLE-3 and Sk-Hep1 cells; $10,20,30,40,50 \mu \mathrm{M}$ of $5 \mathrm{a}$ for the Hep3B and MDA-MB231 cells; 2, 4, 6, 8, $10 \mu \mathrm{M}$ of 5b for the HEK293, THLE-3 and Sk-Hep1 cells; 4, 8, 12, 16, $20 \mu \mathrm{M}$ of $5 \mathrm{~b}$ for the Hep3B and MDA-Mb-231 cells; 20, 40, 60, 80, $100 \mu \mathrm{M}$ of $5 \mathrm{c}$ for the Sk-Hep1, Hep3b and MDA-MB-231 cells) and incubated at $37^{\circ} \mathrm{C}$ for $24 \mathrm{~h}$. Following incubation, $10 \mu \mathrm{l}$ of EZ-Cytox Cell Viability Assay Solution WST- ${ }^{\circledR}$ reagents (Daeil Lab Service, Seoul, Korea) were added to each well followed by further incubation for $4 \mathrm{~h}$ at $37^{\circ} \mathrm{C}$. The absorbance at $460 \mathrm{~nm}$ was measured using a microplate reader (Molecular Devices, Sunnyvale, CA, USA). The $\mathrm{IC}_{50}$ was defined as the compound concentration required to inhibit cell proliferation by $50 \%$, compared with the cells treated with DMSO only (deemed $100 \%$ viable).

Flow cytometry. The cells were treated with different concentrations of the compounds $(12 \mu \mathrm{M} 5 \mathrm{a}$ and $6 \mu \mathrm{M} 5 \mathrm{~b}$ for the Sk-Hep1 cells; $24 \mu \mathrm{M}$ 5a and $11 \mu \mathrm{M}$ 5b for the Hep3B cells; $48 \mu \mathrm{M} 5 \mathrm{a}$ and $20 \mu \mathrm{M} 5 \mathrm{~b}$ for the MDA-MB-231 cells) and incubated for $12 \mathrm{~h}$ at $37^{\circ} \mathrm{C}$. The cells were then harvested by trypsinization and centrifugation for $3 \mathrm{~min}$ at 1,200 rpm at room temperature, washed with phosphate-buffered saline (PBS), and fixed with ice-cold $70 \%$ ethanol for overnight at $4^{\circ} \mathrm{C}$. The fixed cells were collected by centrifugation for 3 min at $1,200 \mathrm{rpm}$ at $4^{\circ} \mathrm{C}$, washed with PBS, snd resuspended in $0.5 \mathrm{ml}$ PBS containing propidium iodide $(40 \mu \mathrm{g} / \mathrm{ml})$ and RNase A $(200 \mu \mathrm{g} / \mathrm{ml})$. The cells were incubated on ice, in the dark, for $30 \mathrm{~min}$. The cell cycle distribution was analyzed using a FACSCalibur flow cytometer (BD Biosciences). 
Deoxycholic acid (DCA) analysis. The cells were divided into 4 groups: i) control; ii) DCA $(5 \mu \mathrm{M})$ only; iii) DCA $(5 \mu \mathrm{M})+5 \mathrm{a}$; and iv) DCA $(5 \mu \mathrm{M})+5 \mathrm{~b}$. The cells were treated with DCA for $30 \mathrm{~min}$ and were then immediately exposed to $5 \mathrm{a}$ and $5 \mathrm{~b}$ compounds independently. Following treatment for $12 \mathrm{~h}$, the total proteins were extracted from the cells and subjected to western blot analyses with antibodies against phosphorylated forms of $\beta$-catenin, E-cadherin, Axin and GSK-3 $\beta$.

Protein extraction and western blot analysis. The cells were incubated in the presence of the compounds, as described, and, were collected at different time intervals, centrifuged at 1,200 $\mathrm{rpm}$ for $3 \mathrm{~min}$ at room temperature and washed twice with ice-cold PBS. The pellets were then resuspended in lysis buffer, containing $50 \mathrm{mM}$ Tris- $\mathrm{Cl}$ (pH 7.5), $150 \mathrm{mM}$ $\mathrm{NaCl}, 1$ mM DTT, $0.5 \%$ NP-40, 1\% Triton X-100, 1\% deoxycholate, $0.1 \%$ sodium dodecyl sulfate (SDS) and a cocktail of protease inhibitors (Intron Biotechnology, Inc., Seoul, Korea). Following lysis of the cells on ice for $1 \mathrm{~h}$, the lysates were centrifuged at $14,000 \mathrm{rpm}$ at $4^{\circ} \mathrm{C}$ for $20 \mathrm{~min}$ and the protein lysates were collected. Equal quantities of $40 \mu \mathrm{g}$ protein were resolved using $12 \%$ SDS-polyacrylamide gel electrophoresis (SDS-PAGE) and transferred onto a nitrocellulose membrane (Pall Life Sciences, Port Washington, NY, USA). The membranes were blocked with PBS buffer with $0.5 \%$ Tween-20, containing $5 \%$ skim milk overnight at $4^{\circ} \mathrm{C}$. The membranes were then incubated with primary antibodies overnight at $4^{\circ} \mathrm{C}$ : p53 $(1: 1,000$, monoclonal, rabbit antihuman, \#2527), p16 (1:1,000, polyclonal, rabbit anti-human, \#4824), $\beta$-catenin (1:1,000, monoclonal, rabbit anti-human, \#8480), phospho- $\beta$-catenin (Ser33/37) (1:1,000, polyclonal, rabbit anti-human, \#2009), E-cadherin (1:1,000, monoclonal, rabbit anti-human, \#3195), Axin (1:1,000, monoclonal, rabbit anti-human, \#2087), GSK-3 $\beta$ (1:1,000, monoclonal, mouse anti-human, \#9832), c-myc (1:1,000, polyclonal, rabbit anti-human, \#9402), Cdk2 (1:1,000, monoclonal, rabbit antihuman, \#2546), p21 (1:1,000, monoclonal, rabbit anti-human, \#2947), p27 (1:1,000, polyclonal, rabbit anti-human, \#2552), MMP-2 (1:1,000, polyclonal, rabbit anti-human, \#4022) and GAPDH (1:1,000, monoclonal, rabbit anti-human, \#5174) (all purchased from Cell Signaling Technology Inc., Beverly, MA, USA); Cyclin D1 (1:1,000, monoclonal, mouse antihuman, ab101430) and phospho- $\beta$-catenin (Tyr142) $(1: 1,000$, polyclonal, rabbit anti-human, ab27798) were purchased from Abcam (Cambridge, UK). The membranes were subsequently incubated with horseradish peroxidase-conjugated antirabbit IgG secondary antibodies $(1: 2,000)$ or anti-mouse IgG second antibodies $(1: 2,000)$ for $1 \mathrm{~h}$ at room temperature. Both secondary antibodies were purchased from Cell Signaling Technology Inc. All membranes were visualized using WestSave $^{\mathrm{TM}}$ Gold ECL (AbFrontier, Inc., Seoul, Korea) and exposed to Hyperfilm (GE Healthcare, Little Chalfont, UK). GAPDH was used as an internal loading control.

Matrigel invasion assay. The invasion of tumor cells was assessed using Matrigel coated Transwell chambers with a $6.5 \mathrm{~mm}$ polyvinyl/pyrrolidone-free polycarbonate filter of $8 \mu \mathrm{m}$ pore size (Corning Life Sciences, Tewksbury, MA, USA), as described previously (18). The cells $\left(5 \times 10^{4}\right.$ each of the Sk-Hep1, Hep3B and MDA-MB-231 cells) and different concentrations of the compounds were suspended in $100 \mu \mathrm{l}$ serum-free media, placed in the upper Transwell chamber and incubated for $24 \mathrm{~h}$ at $37^{\circ} \mathrm{C}$. The cells on the upper surface of the filter were removed completely using a cotton swab, and the lower surface of the filter was fixed with $4 \%$ formaldehyde and stained with crystal violet (Sigma-Aldrich). Following staining, the lower surface cells were lysed with $2 \%$ SDS for $1 \mathrm{~h}$ and the lysate was measured using a microplate reader at $570 \mathrm{~nm}$.

Statistical analysis. The statistical significance of differences between the values of the compound treated and untreated groups was determined using SigmaPlot 11 software (trial version). The results are expressed as the mean \pm standard deviation of three independent experiments. Data were analyzed using one-way analysis of variance followed by Tukey's analysis for multiple comparisons. A P-value $<0.001$ was considered to indicate a statistically significant difference.

\section{Results and Discussion}

In vitro antiproliferative activities. The cytotoxic effects of $5 \mathrm{a}, 5 \mathrm{~b}$ and $5 \mathrm{c}$ were evaluated in human embryonic kidney HEK 293 cells, human normal liver THLE-3 cells, human Sk-Hep1 and Hep3B cells and human breast adenocarcinoma MDA-MB-231 cells. The synthesis and structure of the tetrahydropyridinol derivatives are illustrated in Fig. 1. The effects of 5a and 5b on the viability of HEK293, THLE-3 and Sk-Hep1 cells are shown in Fig. 2A and B. Although the two compounds exhibited cytotoxicity in a dose-dependent manner, 5b exhibited significantly higher cytotoxicity, compared with 5a in the Sk-Hepl cells. By contrast, the two compounds exhibited lower levels of cytotoxicity towards the non-cancerous HEK293 and THLE-3 cells (Fig. 2). The $\mathrm{IC}_{50}$ of compounds $5 \mathrm{a}$ and $5 \mathrm{~b}$ were 12 and $6 \mu \mathrm{M}$ in the Sk-Hep1 cells, respectively. The effectiveness of 5a on the viability of Hep3B and MDA-MB-231 cells was subsequently investigated, and the results revealed that $5 \mathrm{a}$ inhibited the cell proliferation in the two cell lines in a dose-dependent manner (Fig. 2). The $\mathrm{IC}_{50}$ of 5a in Hep3B and MDA-MB-231 cells was 24 and $48 \mu \mathrm{M}$, respectively. Similarly, 5b dose-dependently inhibited the growth of the Hep3B and MDA-MB-231 cells (Fig. 2). The $\mathrm{IC}_{50}$ of $5 \mathrm{~b}$ in the Hep3B and MDA-MB-231 cells was 11 and $20 \mu \mathrm{M}$, respectively. These results suggested that $5 \mathrm{a}$ and $5 \mathrm{~b}$ were potent in inhibiting the proliferation of human HCC and breast adenocarcinoma cells.

The present studyy also assessed the cytotoxicity of $5 \mathrm{c}$ in human HCC (Sk-Hep1 and Hep3B) and breast carcinoma (MDA-MB-231) cells. However, no significant cytotoxicity in was observed in any of the three cell lines was observed at concentrations up to $100 \mu \mathrm{M}$ (Fig. 2). These results indicated that the cytotoxic effects of $5 \mathrm{a}$ and $5 \mathrm{~b}$ compounds were more divergent on human HCC and breast carcinoma cells. Taken together, the investigations of cellular viability revealed that $5 \mathrm{a}$ and $5 \mathrm{~b}$ were significantly effective in inducing cytotoxicity towards Sk-Hep1, Hep3B and MDA-MB-231 cancer cell lines, and had differential inhibitory effects. Among these three cell lines, Sk-Hep1 cells were more sensitive to the two compounds, compared with the other cell lines, and the inhibitory concentrations were considerably less, compared with the Hep3B and MDA-MB-231 cells. However, the 5a and 5b compounds 
A

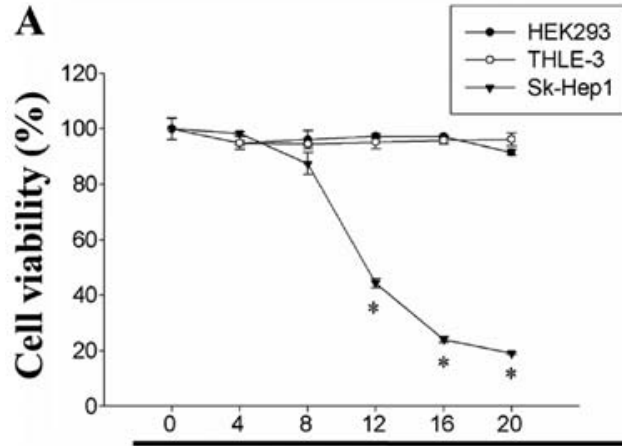

C

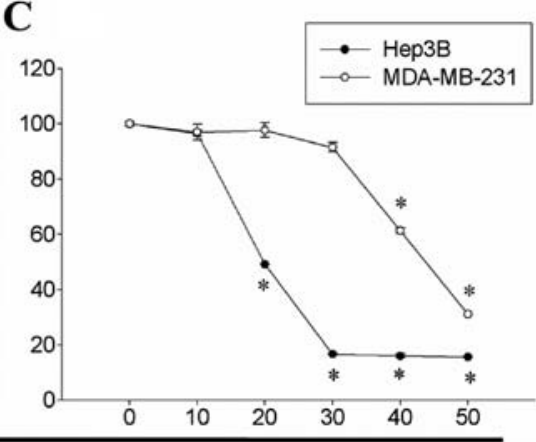

$5 \mathrm{a}(\mu \mathrm{M})$

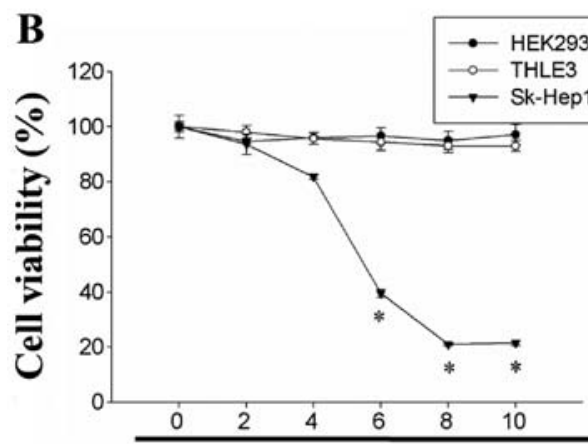

D

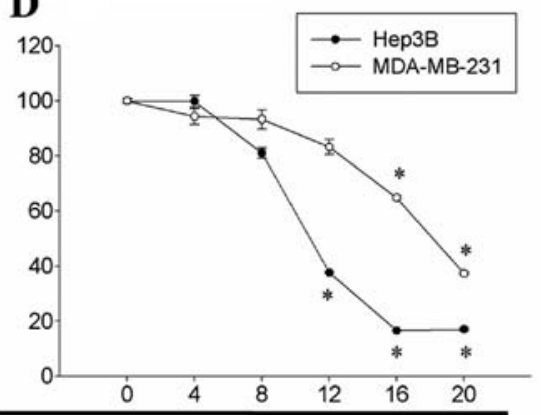

$5 \mathbf{b}(\mu \mathrm{M})$

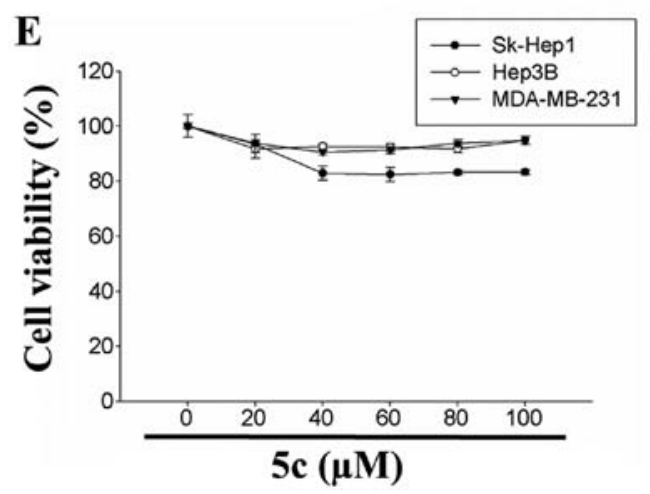

Figure 2. Antiproliferative effect of tetrahydropyridinol derivatives. Dose-dependent effects of (A and B) 5a and (C-D) 5b on the viability of HEK293, THLE-3 and Sk-Hep1, and Hep3B and MDA-MB-231 cells. (E) Dose-dependent effect of 5c on the viability of Sk-Hep1, Hep3B and MDA-MB-231 cells. Cells were treated with indicated concentrations of $5 \mathrm{a}, 5 \mathrm{~b}$ and $5 \mathrm{c}$, respectively for $24 \mathrm{~h}$ followed by measurement of cell viability using WST-1 ${ }^{\circledR}$ reagent. Values are expressed as the mean \pm standard deviation of three independent experiments $(" \mathrm{P}<0.001)$.

were less toxic towards the non-cancerous human embryonic kidney HEK293 cells and human liver THLE-3 cells.

The significant cytotoxicity profiles of the chloroacetyl derivative, compared with the corresponding bromo counterpart and 2-bromopropionyl bromide suggested that the size and electronegativity of the halogens are important, indicating that, compared to bromine, chlorine atoms are smaller in size with increased electronegativity, which may affect its improved cell permeability and favorable interaction with the binding site of its biological target. Furthermore, depending on the nature of substituent at the heterocyclic nitrogen, each of the molecules preferentially exhibit an energetically favorable non-chair conformation, which may also be vital with regard to their individual potency. The poor activity observed with bromofluoro may be due to the increased size from the incorporation of lipophilic methyl group at the $\mathrm{N}$-acetyl functionality.
Compounds $5 a$ and $5 b$ differentially targets $\beta$-catenin signaling in human HCC and breast cancer cells. The present study subsequently examined whether the inhibition of cell proliferation was due to upregulation of tumor suppressor proteins or downregulation of oncogenes. To clarify this, Sk-Hep1 cells were treated with $5 \mathrm{a}$ and $5 \mathrm{~b}$ independently for different time intervals, and the expression of HCC deregulated proteins, $\mathrm{p} 53$, p16 and $\beta$-catenin, were examined using western blotting. The blots revealed that the expression of $\beta$-catenin was downregulated in a time-dependent manner by the two compounds (Fig. 3A), whereas no change in the expression of the p53 and p16 tumor suppressor proteins was observed (Fig. 3A). Following treatment for $12 \mathrm{~h}$, the expression level of $\beta$-catenin was completely inhibited by $5 \mathrm{a}$ and $5 \mathrm{~b}$ in the Sk-Hep1 cells. The inhibitory effects of $5 \mathrm{a}$ and $5 \mathrm{~b}$ were also analyzed in Hep3B cells. The results demonstrated that 
A

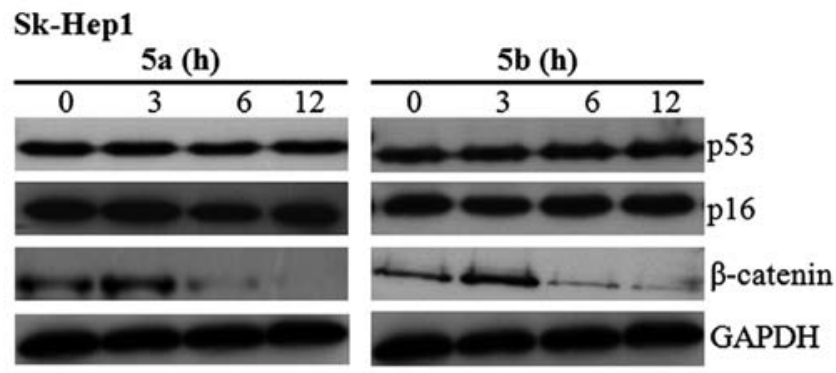

$\mathbf{B}$

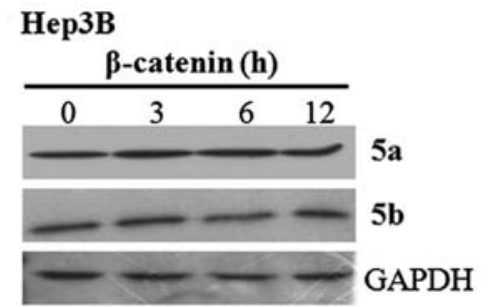

Figure 3. Effects of 5a and $5 \mathrm{~b}$ on the expression of deregulated proteins in hepatocellular carcinoma. (A) Sk-Hep1 and (B) Hep3B cells were treated with 5a and $5 \mathrm{~b}$ independently for the indicated durations, up to $12 \mathrm{~h}$, and subjected to western blot analysis against $\mathrm{p} 53$, p16 and $\beta$-catenin. No changes in the expression levels of 553 and p16 were observed, only the expression of $\beta$-catenin was affected. GAPDH, glyceraldehyde 3-phosphate dehydrogenase.

A
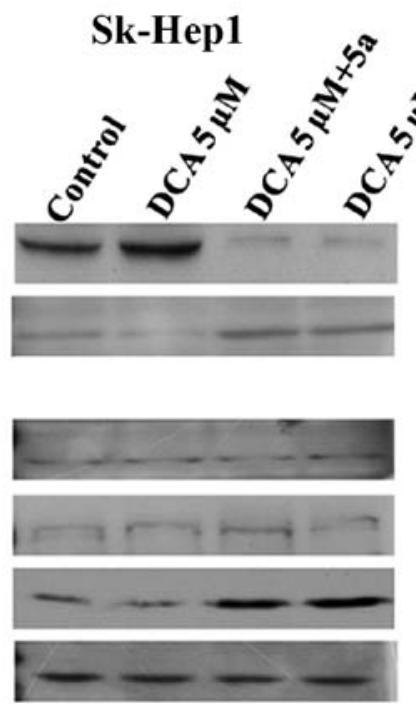

p- $\beta$-catenin(Tyr 142)

$\mathrm{p}-\beta$-catenin $(\operatorname{Ser} 33 / 37)$

E-cadherin
Axin
GSK-3 $\beta$
GAPDH

B
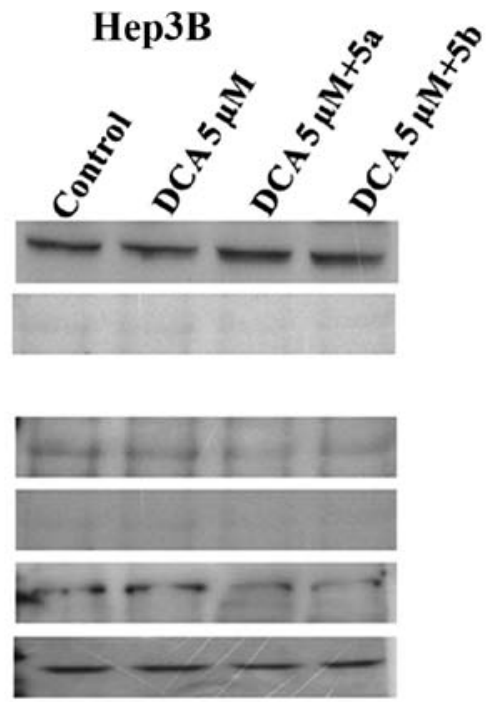

Figure 4. Effects of $5 \mathrm{a}$ and $5 \mathrm{~b}$ on DCA-induced phosphorylated $\beta$-catenin and its signaling proteins. (A) Sk-Hep1 and (B) Hep3B cells were treated with DCA $(5 \mu \mathrm{M})$ for $30 \mathrm{~min}$ and then immediately exposed to $5 \mathrm{a}, 5 \mathrm{~b}$ or dimethyl sulfoxide (control) for $12 \mathrm{~h}$. The proteins were then extracted and subjected to

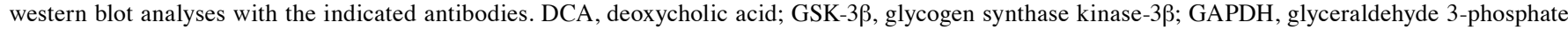
dehydrogenase; p-phosphorylated.

the expression of $\beta$-catenin was not altered, and its expression levels were maintained throughout treatment (Fig. 3B). These results raises the question of whether these compounds specifically inhibit either the expression or activity of $\beta$-catenin in Sk-Hep1 cells.

In order to address this question, DCA, which specifically activates the phosphorylation of $\beta$-catenin (19) was used. For this analysis, the cells were divided into four groups: i) control; ii) DCA $(5 \mu \mathrm{M})$ only;iii) DCA $(5 \mu \mathrm{M})+5 \mathrm{a}$; and iv) DCA $(5 \mu \mathrm{M})+5 \mathrm{~b}$. DCA was treated for $30 \mathrm{~min}$ and then immediately exposed the cells to $5 \mathrm{a}$ and $5 \mathrm{~b}$ compounds independently. Following treatment for $12 \mathrm{~h}$, the proteins were extracted from the cells and subjected to western blot analyses with antibodies against the phosphorylated forms of $\beta$-catenin. The results of the western blotting revealed that, in the Sk-Hep1 cells, the expression of phospho- $\beta$-catenin (Tyr142) was increased in the DCA only group and decreased in the DCA $+5 a$ and DCA $+5 b$ groups (Fig. 4A), whereas the expression of phospho- $\beta$-catenin (Ser33/37) was not significantly different to those in the DCA $+5 a$ and DCA+5b compound groups (Fig. 4A). However, this type of expression pattern was not observed in Hep3B cells (Fig. 4B). The phosphorylation of $\beta$-catenin at Ser33/37 by GSK-3 $\beta$ and the association of $\beta$-catenin with other tumor suppressor proteins, Axin and APC, lead to ubiquitinization of $\beta$-catenin and subsequently targets degradation by the ubiquitin-proteosome complex (20). By contrast, the phosphorylation of $\beta$-catenin at Tyr142 inhibits the incorporation of $\beta$-catenin with the Axin-APC complex, which leads to accumulation of $\beta$-catenin in the cytoplasm and subsequent export to the nucleus. In the nucleus, $\beta$-catenin, in associa- 
A
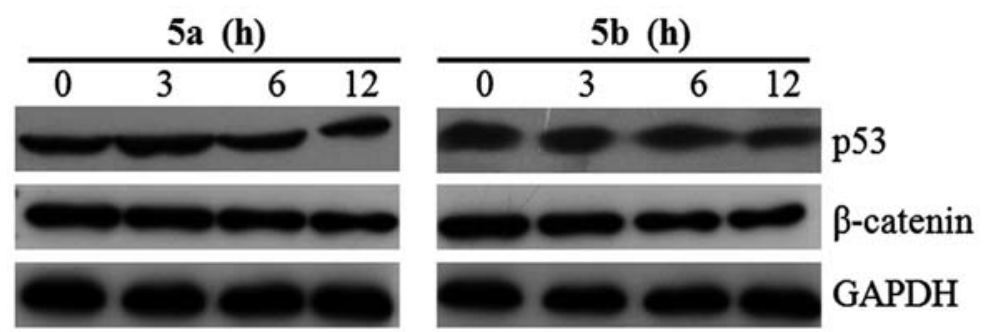

B

5a (h)

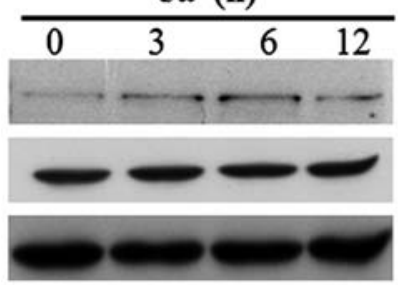

$5 \mathrm{~b}$ (h)

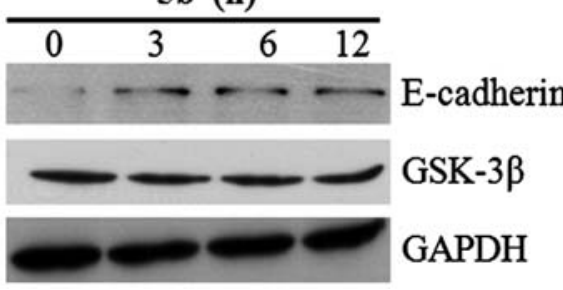

Figure 5. Effects of 5a and 5b on the expression levels of tumor suppressor and $\beta$-catenin signaling proteins in MDA-MB-231 cells. Cells were treated with either $5 \mathrm{a}$ or $5 \mathrm{~b}$ for the indicated durations, up to $12 \mathrm{~h}$, and the extracted proteins were subjected to western blot analysis with (A) p53, $\beta$-catenin, (B) E-cadherin and GSK-3 $\beta$ antibodies. GSK 3 $\beta$, glycogen synthase kinase-3 $\beta$; GAPDH, glyceraldehyde 3-phosphate dehydrogenase.

tion with its nuclear binding partners, TCF and LEF, initiates transcription of the $\beta$-catenin-targeted genes, cyclin D1 and c-myc (20-22). The c-myc and cyclin D1 promoters contain TCF-binding sites, which mediate transcriptional activation via the $\mathrm{TCF} / \beta$-catenin complex. The results of the present study suggeste that compounds $5 \mathrm{a}$ and $5 \mathrm{~b}$ inhibited active $\beta$-catenin expression in highly invasive Sk-Hepl cells only, but not in the Hep3B cells (Fig. 4B).

The present study also investigated whether these compounds inhibit only $\beta$-catenin, or affect any other proteins in the $\beta$-catenin signaling pathway. Using western blot analysis, the expression of E-cadherin, a metastasis-suppressor protein, Axin1, a tumor-suppressor protein, and GSK-3 $\beta$ were examined. The resulting data demonstrated that, in the Sk-Hep1 cells, the expression levels of E-cadherin and Axin1 were low in the control group, and their levels of expression were not altered by these compounds (Fig. 4A). By contrast, these compounds upregulated the expression of GSK-3 $\beta$ (Fig. 4A), which resulted in the phosphorylation of $\beta$-catenin at the Ser33/37 residue and facilitated its degradation. In the Hep3B cells, this upregulation was not observed, with the proteins expressed at a low level and remaining unchanged (Fig. 4B). The levels of $\beta$-catenin in the cells is tightly controlled by its degradation complexm composed of Axin, APC, GSK-3 $\beta$ and $\beta$-catenin, in which GSK-3 $\beta$ phosphorylates $\beta$-catenin and thus triggers its ubiquitination and subsequent proteosomal degradation (20). Similarly, the downregulation of E-cadherin is more frequently achieved by promoter hypermethylation in tumor cells, particularly in HCC (23). The overexpression of $\beta$-catenin and downregulation of E-cadherin in poorly differentiated, highly invasive cancers implicates the involvement of E-cadherin and $\beta$-catenin in the progression of cancer (24). The inhibition of $\beta$-catenin, and the upregulation of GSK-3 $\beta$ and E-cadherin may be crucial for restraining the progression of cancer. Overexpression of Axin1 in mammalian cells results in a decrease in levels of $\beta$-catenin and suppression of TCF-dependent gene transcription (25). Together, the results suggested that, particularly in highly invasive Sk-Hep1 cells, 5a and $5 \mathrm{~b}$ inhibited the elevated expression of phospho- $\beta$-catenin (Tyr142), and the upregulation of GSK-3 $\beta$ by these compounds phosphorylated free cytoplasmic $\beta$-catenin at Ser33/37 residues, which, tagged with the ubiquitin, lead to the degradation of $\beta$-catenin.

In order to further confirm the above-mentioned results, the highly invasive breast cancer, MDA-MB-231, cell line was examined. The MDA-MB-231 cells were exposed to $5 \mathrm{a}$ and $5 \mathrm{~b}$ independently, and western blot analysis against $\beta$-catenin and p53 was performed. The results demonstrated no changes in the expression levels of $\beta$-catenin or p53 (Fig. 5A). Therefore, the expression of $\beta$-catenin binding partner, E-cadherin and GSK-3 $\beta$, were examined. The two compounds upregulated the expression of E-cadherin, however, the expression of GSK-3 $\beta$ was not altered (Fig. 5B). These results demonstrated that $5 \mathrm{a}$ and $5 \mathrm{~b}$ stimulated the expression of E-cadherin, suggesting significant attachment may occur between E-cadherin and $\beta$-catenin. Several studies have described a partial or complete loss of E-cadherin during cancer progression (26-28). The role of E-cadherin as a tumor suppressor protein and the dual role of its binding partner, $\beta$-catenin, in cell adhesion and Wnt signaling may indicate a function for E-cadherin in the Wnt pathway. In the absence of an appropriate Wnt signal, E-cadherin may sequester $\beta$-catenin at the cell membrane, thereby preventing the formation of TCF- $\beta$-catenin complexes in the nucleus. Mutation of E-cadherin in cancer cells may disrupt the interaction with $\beta$-catenin. This disruption inhibits the formation of destruction complex of $\beta$-catenin with APC, Axin and GSK-3 $\beta$ (29). In the presnt study, the compounds differentially targetEd the $\mathrm{Wnt} / \beta$-catenin signaling by inhibiting the expression of $\beta$-catenin in the Sk-Hep1 cells and upregulating the expression of GSK-3 $\beta$ and E-cadherin in the Sk-Hep1 and MDA-MB-231 cells, respectively, specifically modulating the activity of $\mathrm{Wnt} / \beta$-catenin signaling in highly invasive cancer cells.

Compounds $5 a$ and $5 b$ induce 61 phase arrest. In the nucleus, $\beta$-catenin, in association with TCF/LEF, initiates transcription 
A

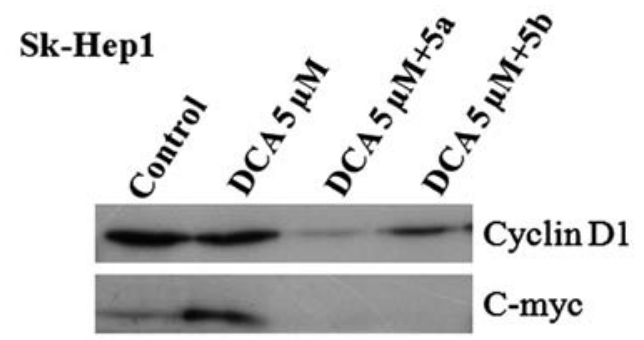

B Hep3B

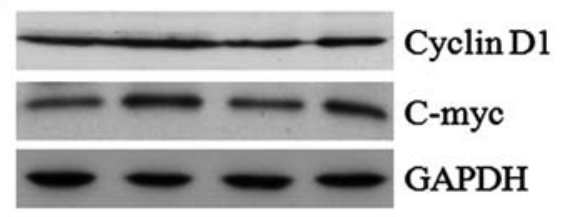

\section{MDA-MB-231}

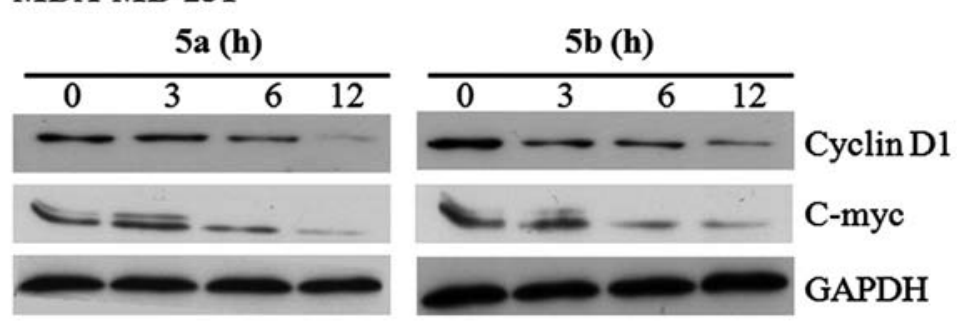

Figure 6. Compounds 5a and 5b modulate the expression of $\beta$-catenin target genes. (A) Sk-Hep1 and (B) Hep3B cells were treated with $5 \mu \mathrm{M}$ DCA for 30 min and then immediately exposed to the $5 \mathrm{a}$ or $5 \mathrm{~b}$ compounds or dimethyl sulfoxide (control) for $12 \mathrm{~h}$. (C) MDA-MB-231 cells were treated with either $5 \mathrm{a}$ or $5 \mathrm{~b}$ for the indicated durations. The expression levels of cyclin D1 and c-myc were detected using western blot analysis. GAPDH was used as an internal loading control. DCA, deoxycholic acid; glyceraldehyde 3-phosphate dehydrogenase; p-phosphorylated.

of its downstream target genes, particularly c-myc and cyclin D1 (20-22). To determine whether these compounds modulate the expression of $\beta$-catenins target genes, cyclin D1 and c-myc, western blot analysis was performed using the proteins of the Sk-Hep1, Hep3B and MDA-MB-231 cells. The blots revealed that the expression levels of cyclin D1 and c-myc were inhibited in the Sk-Hep1 and MDA-MB-231 cells by the two compounds (Fig. 6). However, the expression levels of these $\beta$-catenin target proteins were not inhibited and remained unchanged in the Hep3B cells (Fig. 6).

The present study subsequently examined whether $5 \mathrm{a}$ and $5 b$ induced the downregulation of cyclin D1 in either Sk-Hep1 or MDA-MB-231 cells, and where growth inhibition of Hep3B cells was caused by cell cycle arrest. To address this question, the cells were treated independently with $5 \mathrm{a}$ and $5 \mathrm{~b}$ at $\mathrm{IC}_{50}$ concentrations for $12 \mathrm{~h}$, fixed, and cell cycle populations were determined using flow cytometry. The results demonstrated that the percentage of the cell population in the G1 phase was significantly higher in all three cell lines, compared with the untreated control group (Fig. 7). These results confirmed that the growth of Hep3B cells was inhibited by cell cycle arrest, whereas the growth inhibition in Sk-Hep1 and MDA-MB-231 cells was mediated by $\mathrm{Wnt} / \beta$-catenin signaling. The expression levels of cell cycle regulatory proteins, p21, p27 and CDK2, were also examined in the Hep3B cells. The expression levels of p21 and p27 were significantly upregulated in the Hep3B cells following treatment with either of the two compounds, and CDK2 was significantly decreased following treatment (Fig. 8). In mammalian cells, cyclin D,
E and A are synthesized sequentially during the G1 phase of the cell cycle. The major catalytic partners of these cyclins are CDK2 and CDK4, which are negatively regulated by CDK-inhibitors, including p21, p27 and p53 $(30,31)$. The p53 tumor suppressor is required for the transcriptional activation of p21 (32). Previously, indole-3-carbinol tetrameric derivative has been observed to induce G1 cell cycle arrest in breast cancer cells by upregulating p27kip1 (33). In the present study, as expected, p21 and p27 were induced by 5a and $5 \mathrm{~b}$ via a $\mathrm{p} 53$-independent pathway in the Hep3B cells (p53 null type). These results suggested that downregulation of the expression of cyclin D1 and CDK2, and the induction of p21 and p27, had a suppressive effect on the growth of the Sk-Hep1, Hep3B and MDA-MB-231 cells. Taken together, compounds $5 \mathrm{a}$ and $5 \mathrm{~b}$ inhibited the progression of cell cycle differentially through $\mathrm{Wnt} / \beta$-catenin mediation in the Sk-Hep1 and MDA-MB-231 cells, and via p53-independent cell cycle arrest in Hep3B cells.

Effects of 5 and $5 b$ on invasion of Sk-Hepl and MDA-MB-231 cells. Non-phosphorylated $\beta$-catenin accumulates in the cytoplasm and, when activated, it enters the nucleus and interacts with TCF/LEF to control various target genes, which are involved in cellular proliferation and metastasis (10). Since metastasis is the leading cause of mortality in human cancer (10), the present study assessed the chemotherapeutic effects of $5 \mathrm{a}$ and $5 \mathrm{~b}$ on the invasive potential of human HCC and breast carcinoma cells. For this purpose, a Matrigel invasion assay was performed using the Sk-Hep1, Hep3B and 


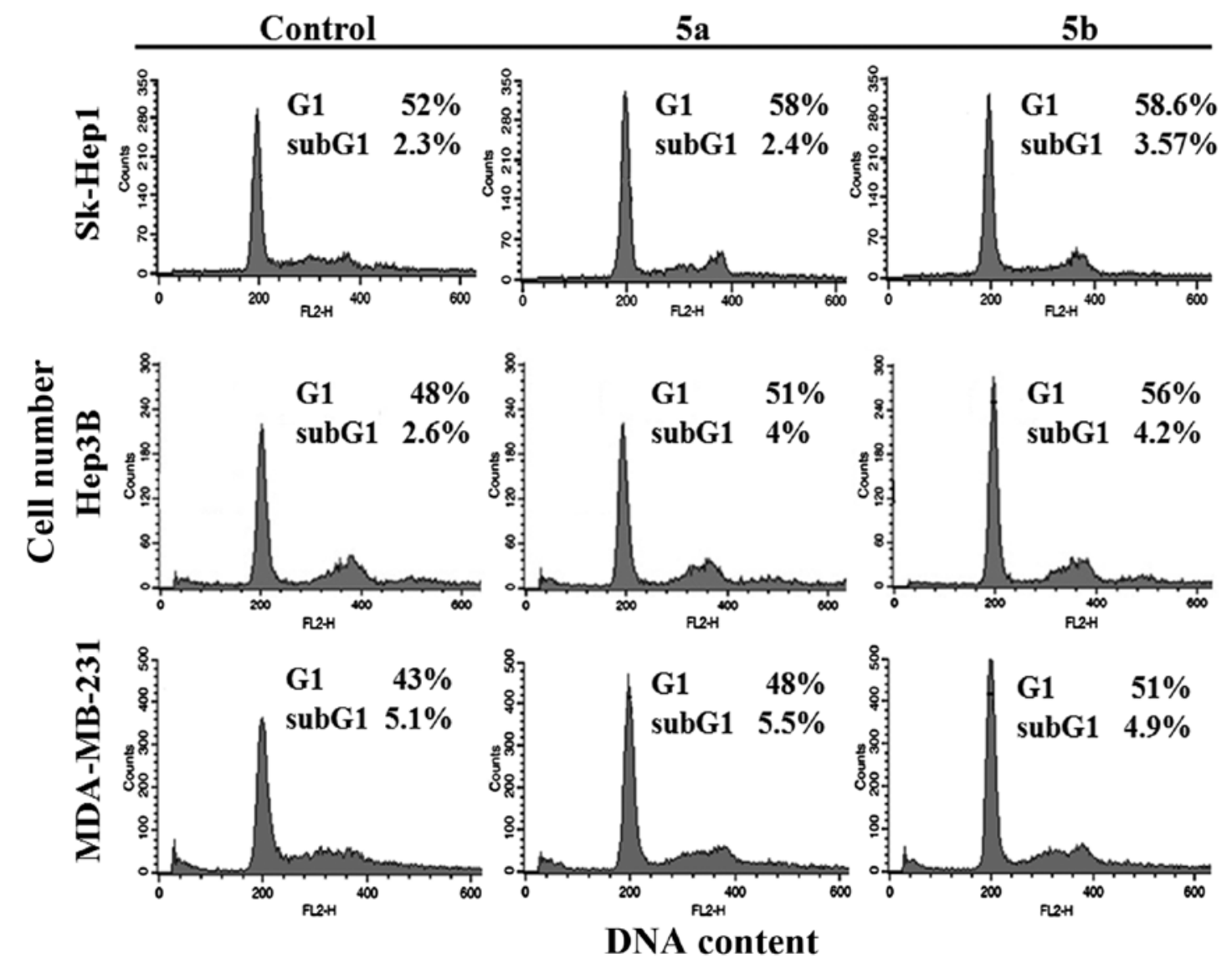

Figure 7. Effects of 5a and 5b on the cell cycle distribution of the Sk-Hep1, Hep3B and MDA-MB-232 cells. The cells were treated with the indicated compounds for $12 \mathrm{~h}$, stained with propidium iodide and analyzed for DNA content using flow cytometry. The percentages indicate the proportion of cells in the respective cell cycle stages.
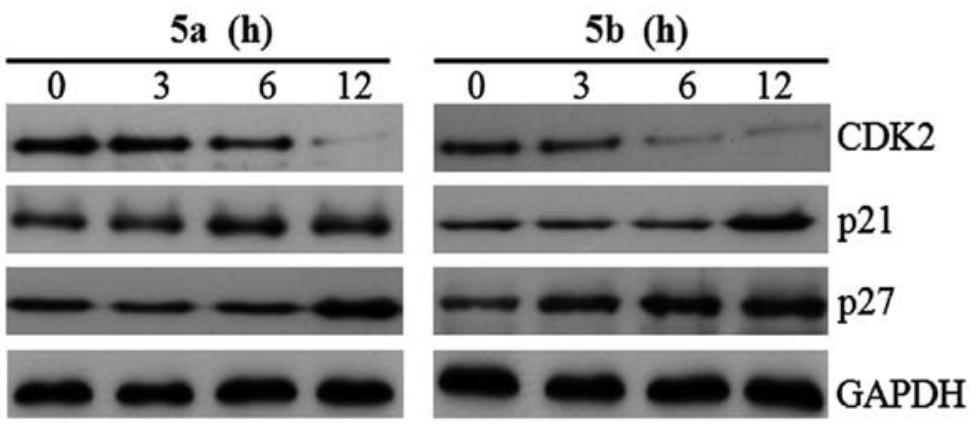

Figure 8. Alterations in the expression levels of cell cycle regulatory proteins by $5 \mathrm{a}$ and $5 \mathrm{~b}$. Western blot analyses of CDK2, p21 and p27 in Hep3B cells treated with half maximal inhibitory concentration concentrations of $5 \mathrm{a}$ and $5 \mathrm{~b}$ individually. GAPDH was probed as an internal control. GAPDH, glyceraldehyde 3-phosphate dehydrogenase.

MDA-MB-231 cells. The results of the invasion assay reveled that the invasive potential of highly metastatic Sk-Hep1 and MDA-MB-231 cells was decreased dose-dependently by $5 \mathrm{a}$ and $5 \mathrm{~b}$ compounds (Fig. 9A), whereas, in non-metastatic Hep3B cells, these compounds were not functional (Fig. 9A). The the expression of MMP-2 was then determined in the Sk-Hep1 and MDA-MB-231 cells, as MMP-2 is involved in the process of invasion and its inhibition may be crucial for the suppression of cancer metastasis. The results demonstrated that the expression of MMP-2 was reduced after $12 \mathrm{~h}$ treatment with 5a and 5b in the Sk-Hep1 and MDA-MB-231 cells
(Fig. 9B). The expression of MMPs, including MMP-2 has been observed to be important in the degradation of the basement membrane in cancer invasion and is associated with tumor metastasis (34). The expression of cell adhesion molecule, including E-cadherin, is also associated with the invasiveness of tumor cells. High expression levels of E-cadherin are reported to correlate with a low invasive potential of cells, whereas low levels of the expression are associated with increased invasiveness $(35,36)$. Hispoplan and lycopene inhibits metastasis in Sk-Hep1 cells by downregulating the expression levels of MMP-2 and MMP-9 $(37,38)$. It has been 
$\mathbf{A}$

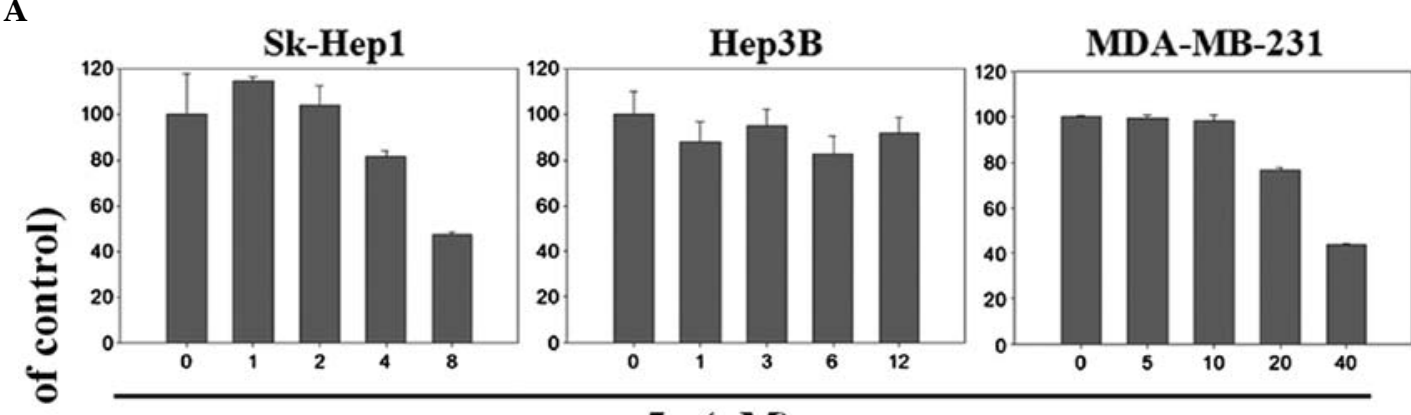

$5 \mathbf{a}(\mu \mathrm{M})$
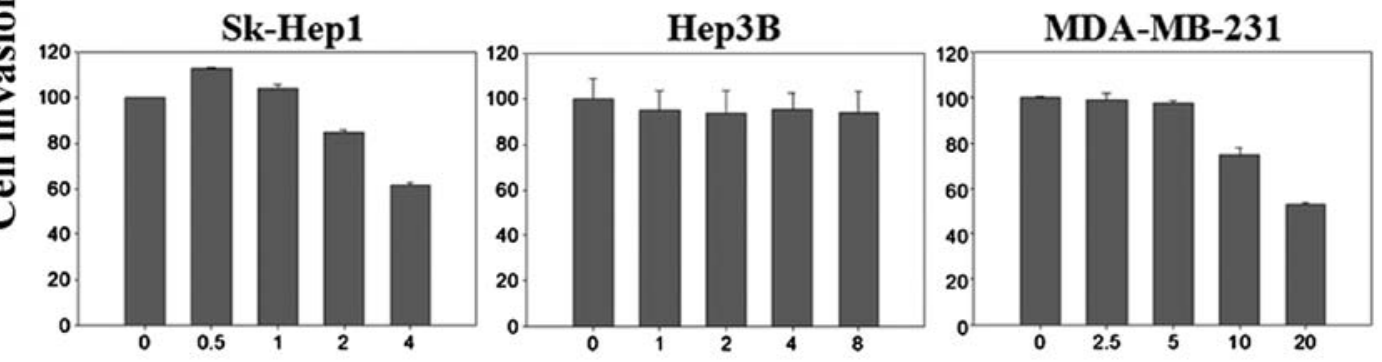

$5 \mathbf{b}(\mu \mathrm{M})$

B

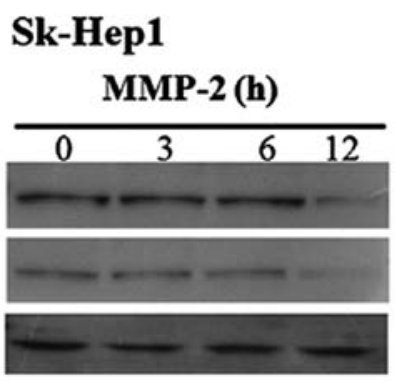

MDA-MB-231

MMP-2 (h)

5a

$\mathbf{5 b}$

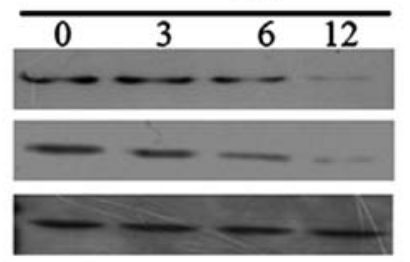

Figure 9. Compounds 5a and 5b inhibit the invasive potential of Sk-Hep1 and MDA-MB-231 cells in a concentration-dependent manner. (A) Cell suspension $\left(100 \mu 15 \times 10^{4}\right.$ cells) from each cell lines was added to the wells coated with Matrigel and treated with the indicated concentrations of $5 \mathrm{a}$ or $5 \mathrm{~b}$ for $24 \mathrm{~h}$ at $37^{\circ} \mathrm{C}$. The cells were stained with crystal et, lysed with $2 \%$ sodium dodecyl sulfate and absorbance was measured at 570 nm. Values were normalized to $100 \%$ for the untreated group. Data are expressed as the mean \pm standard deviation of three separate experiments. (B) Changes in the expression of MMP-2, determined using western blot analysis. Sk-Hep1 and MDA-MB-231 cells were treated with the compounds for the indicated durations. MMP-2. matrix metalloproteinase-2; GAPDH, glyceraldehyde 3-phosphate dehydrogenase.

reported that suppression of breast cancer invasion and migration by indole-3-carbinol is associated with the upregualtion of E-cadherin/catenin complex (39). The results of the present study suggested that the downregulation of $\beta$-catenin, as well as the inhibition of MMP-2 may facilitate the inhibition of invasion potential of Sk-Hep1 and MDA-MB-231 cells. As the level of $\beta$-catenin was not downregulated in the Hep3B cells, the inhibition of invasion was not observed, and further confirmed that the inhibitory effect was associated with the $\beta$-catenin signaling pathway.

In conclusion, accumulating evidence has suggested that several natural compounds may be used alone or in combination with traditional chemotherapeutic agents to prevent the occurrence of cancer and its metastatic spread. In addition, several non-steroid inflammatory drugs may target directly or indirectly to $\beta$-catenin signaling. The findings of the present study suggested that compounds $5 \mathrm{a}$ and $5 \mathrm{~b}$ have the ability to interfere $\beta$-catenin signaling by downregulating $\beta$-catenin and its target genes in Sk-Hep1 cells, upregulate the expression of E-cadherin in MDA-MB-231 cells and also inhibit the invasive potential of Sk-Hep1 and MDA-MB-231 cells. In Hep3B cells, however, these compounds did not affect the $\beta$-catenin pathway, and affected only the cell cycle progression by modulating the cell cycle regulatory proteins. These results suggested that $5 \mathrm{a}$ and $5 \mathrm{~b}$ are specific for highly invasive cells and inhibit cell proliferation and invasion by targeting the $\beta$-catenin signaling pathway. Thus, the antiproliferative and anti-invasive activitievs of $5 \mathrm{a}$ and $5 \mathrm{~b}$ could serve as a basis for chemopreventative therapy in human HCC and breast carcinoma. Further investigations are required to fully elucidate the signaling pathways in other invasive and non-invasive cancer cell lines, and in vivo. 


\section{Acknowledgements}

This study was supported by a grant from the Next Generation Bio Green 21 Program, Rural Development Administration, Republic of Korea (grant. no. SSAC-PJ01106901 to W.-Y.K. and SSAC-PJ01137901 to S.Y.L.).

\section{References}

1. Jemal A, Bray F, Center MM, Ferlay J, Ward E and Forman D: Global cancer statistics. CA Cancer J Clin 61: 69-90, 2011.

2. Ries L, Melbert D, Krapcho M, Stinchcomb D, Howlader N, Horner M, Mariotto A, Miller B, Feuer E and Altekruse S: SEER Cancer Statistics Review. Based on November 2007 SEER data submission, posted to the SEER web site. National Cancer Institute, Bethesda, MD, 2008.

3. Roayaie S, Blume IN, Thung SN, Guido M, Fiel MI, Hiotis S, Labow DM,Llovet JM and Schwartz ME: A system of classifying microvascular invasion to predict outcome after resection in patients with hepatocellular carcinoma. Gastroenterology 137: 850-855, 2009.

4. Lang L: FDA approves sorafenib for patients with inoperable liver cancer. Gastroenterology 134: 379, 2008.

5. Clevers $\mathrm{H}$ : Wnt/beta-catenin signaling in development and disease. Cell 127: 469-480, 2006.

6. Cadigan KM: Wnt- $\beta$-catenin signaling. Curr Biol 18: R943-R947, 2008.

7. Kemler R: From cadherins to catenins: cytoplasmic protein interactions and regulation of cell adhesion. Trends Genet 9: 317-321, 1993.

8. Jamora $\mathrm{C}$ and Fuchs E: Intercellular adhesion, signalling and the cytoskeleton. Nat Cell Biol 4: E101-E108, 2002.

9. Clevers H: Wnt/ $\beta$-catenin signaling in development and disease. Cell 127: 469-480, 2006.

10. Polakis P: The many ways of Wnt in cancer. Curr Opin Genet Dev 17: 45-51, 2007.

11. Zucman-Rossi J, Benhamouche S, Godard C, Boyault S, Grimber G, Balabaud C, Cunha A, Bioulac-Sage P and Perret C: Differential effects of inactivated Axin 1 and activated $\beta$-catenin mutations in human hepatocellular carcinomas. Oncogene 26: 774-780, 2007.

12. Fujie H, Moriya K, Shintani Y, Tsutsumi T, Takayama T, Makuuchi M, Kimura S and Koike K: Frequent beta-catenin aberration in human hepatocellular carcinoma. Hepatol Res 20: 39-51, 2001.

13. Kim YD, Park CH, Kim HS, Choi SK, Rew JS, Kim DY, Koh YS, Jeung KW, Lee KH and Lee JS: Genetic alterations of Wnt signaling pathway-associated genes in hepatocellular carcinoma. J Gastroenterol Hepatol 23: 110-118, 2008.

14. Laurent-Puig P and Zucman-Rossi J: Genetics of hepatocellular tumors. Oncogene 25: 3778-3786, 2006.

15. Aridoss G, Amirthaganesan S, Kumar NA, Kim JT, Lim KT, Kabilan S and Jeong YT: A facile synthesis, antibacterial, and antitubercular studies of some piperidin-4-one and tetrahydropyridine derivatives. Bioorg Med Chem Lett 18: 6542-6548, 2008.

16. Aridoss G, Amirthaganesan S and Jeong YT: Synthesis, crystal and antibacterial studies of diversely functionalized tetrahydropyridin-4-ol. Bioorg Med Chem Lett 20: 2242-2249, 2010.

17. Awasthi N, Schwarz MA, Verma V, Cappiello C and Schwarz RE: Endothelial monocyte activating polypeptide II interferes with VEGF-induced proangiogenic signaling. Lab Invest 89: 38-46, 2009.

18. Hung WC and Chang HC: Indole-3-carbinol inhibits Sp1-induced matrix metalloproteinase-2 expression to attenuate migration and invasion of breast cancer cells. J Agric Food Chem 57: 76-82, 2009.

19. Pai R, Tarnawski AS and Tran T: Deoxycholic acid activates $\beta$-catenin signaling pathway and increases colon cell cancer growth and invasiveness. Mol Biol Cell 15: 2156-2163, 2004.

20. MacDonald BT, Tamai K and He X: Wnt/ $\beta$-catenin signaling: components, mechanisms, and diseases. Dev Cell 17: 9-26, 2009.
21. Tetsu $\mathrm{O}$ and McCormick F: $\beta$-catenin regulates expression of cyclin D1 in colon carcinoma cells. Nature 398: 422-426, 1999.

22. He TC, Sparks AB, Rago C, Hermeking H, Zawel L, da Costa LT, Morin PJ, Vogelstein B and Kinzler KW: Identification of c-MYC as a target of the APC pathway. Science 281: 1509-1512, 1998.

23. Wei Y, Van Nhieu JT, Prigent S, Srivatanakul P, Tiollais $P$ and Buendia MA: Altered expression of E-cadherin in hepatocellular carcinoma: correlations with genetic alterations, $\beta$-catenin expression, and clinical features. Hepatology 36: 692-701, 2002.

24. Matsumura T, Makino R and Mitamura K: Frequent down-regulation of E-cadherin by genetic and epigenetic changes in the malignant progression of hepatocellular carcinomas. Clin Cancer Res 7: 594-599, 2001.

25. Sakanaka C, Weiss JB and Williams LT: Bridging of $\beta$-catenin and glycogen synthase kinase- $3 \beta$ by axin and inhibition of $\beta$-catenin-mediated transcription. Proc Natl Acad Sci USA 95: 3020-3023, 1998.

26. Acs G, Lawton TJ, Rebbeck TR, LiVolsi VA and Zhang PJ: Differential expression of E-cadherin in lobular and ductal neoplasms of the breast and its biologic and diagnostic implications. Am J Clin Pathol 115: 85-98, 2001.

27. Rakha EA, Patel A, Powe DG, et al: Clinical and biological significance of E-cadherin protein expression in invasive lobular carcinoma of the breast. Am J Surg Pathol 34: 1472-1479, 2010.

28. Gould Rothberg BE and Bracken MB: E-cadherin immunohistochemical expression as a prognostic factor in infiltrating ductal carcinoma of the breast: a systematic review and meta-analysis. Breast Cancer Res Thr 100: 139-148, 2006.

29. Orsulic S, Huber O, Aberle H, Arnold S and Kemler R: E-cadherin binding prevents beta-catenin nuclear localization and beta-catenin/LEF-1-mediated transactivation. J Cell Sci 112: 1237-1245, 1999

30. Harper JW and Elledge SJ: Cdk inhibitors in development and cancer. Curr Opin Genet Dev 6: 56-64, 1996.

31. Yew PR: Ubiquitin-mediated proteolysis of vertebrate G1- and S-phase regulators. J Cell Physiol 187: 1-10, 2001.

32. Zeng YX and el-Deiry WS: Regulation of p21WAF1/CIP1 expression by p53-independent pathways. Oncogene 12: 1557-1564, 1996.

33. Brandi G, Paiardini M, Cervasi B, Fiorucci C, Filippone $\mathrm{P}$, De Marco C, Zaffaroni $\mathrm{N}$ and Magnani M: A new indole-3-carbinol tetrameric derivative inhibits cyclin-dependent kinase 6 expression, and induces G1 cell cycle arrest in both estrogen-dependent and estrogen-independent breast cancer cell lines. Cancer Res 63: 4028-4036, 2003.

34. Nakajima M, Welch DR, Belloni PN and Nicolson GL: Degradation of basement membrane type IV collagen and lung subendothelial matrix by rat mammary adenocarcinoma cell clones of differing metastatic potentials. Cancer Res 47: 4869-4876, 1987.

35. Mareel MM, Van Roy FM and De Baetselier P: The invasive phenotypes. Cancer Metastasis Rev 9: 45-62, 1990.

36. Christofori $G$ and Semb H: The role of the cell-adhesion molecule E-cadherin as a tumour-suppressor gene. Trends Biochem Sci 24: 73-76, 1999.

37. Huang GJ, Yang CM, Chang YS, Amagaya S, Wang HC, Hou WC, Huang SS and Hu ML: Hispolon suppresses SK-Hep1 human hepatoma cell metastasis by inhibiting matrix metalloproteinase-2/9 and urokinase-plasminogen activator through the PI3K/Akt and ERK signaling pathways. J Agric Food Chem 58: 9468-9475, 2010.

38. Hwang ES and Lee HJ: Inhibitory effects of lycopene on the adhesion, invasion, and migration of SK-Hep1 human hepatoma cells. Exp Biol Med 231: 322-327, 2006.

39. Meng Q, Qi M, Chen DZ, Yuan R, Goldberg ID, Rosen E, Auborn $\mathrm{K}$ and Fan S: Suppression of breast cancer invasion and migration by indole-3-carbinol: associated with up-regulation of BRCA1 and E-cadherin/catenin complexes. J Mol Med 78: 155-165, 2000. 